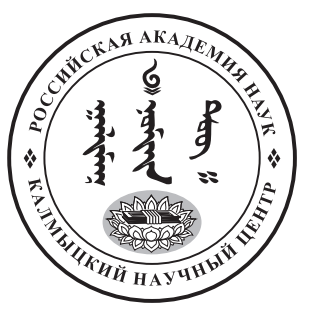

Published in the Russian Federation

Oriental Studies (Previous Name: Bulletin of the Kalmyk Institute

for Humanities of the Russian Academy of Sciences)

Has been issued as a journal since 2008

ISSN: 2619-0990; E-ISSN: 2619-1008

Vol. 14, Is. 5, pp. 900-909, 2021

Journal homepage: https://kigiran.elpub.ru

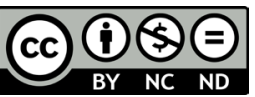

УДК / UDC 94(47)

DOI: $10.22162 / 2619-0990-2021-57-5-900-909$

\title{
Царицынская сторожевая линия и военно-политические изменения на юго-восточных границах России в 1720-х гг.
}

\author{
Александр Леонидович Клейтман ${ }^{1,2}$
}

${ }^{1}$ Волгоградский институт управления - филиал Российской академии народного хозяйства и государственной службы (д. 8, ул. Гагарина, 400131 Волгоград, Российская Федерация) доктор исторических наук, доцент

2 Волгоградский областной научно-производственный центр по охране памятников истории и культуры (д. 19, ул. Коммунистическая, 400131 Волгоград, Российская Федерация)

доктор исторических наук, директор

0000-0003-4779-0321. E-mail: malk@bk.ru

(C) КалмНЦ РАН, 2021

(С) Клейтман А. Л., 2021

Аннотация. Введение. Хотя Царицынская сторожевая линия привлекала внимание историков с XVIII в., специального исследования, посвященного истории Царицынской линии в 1720 -х гг., до настоящего времени предпринято не было. Именно в это время стала проводиться политика по усилению военно-политического влияния России в Прикаспийском регионе: был предпринят Персидский поход, стал усиливаться контроль над передвижениями калмыков. В статье показано, какую роль в данных событиях сыграла Царицынская сторожевая линия. Материаль и методы. Исследование систематизирует, переосмысливает сведения о Царицынской линии, изложенные в историографии, посвященной истории Персидского похода, истории калмыков, истории полков российской императорской армии, дополняет их данными опубликованных и сохранившихся в архивах законодательных актов и делопроизводственной документации. Результаты. Царицын и Царицынская линия были перевалочными пунктами на пути формирования и движения Низового корпуса, через которые проходили практически все воинские подразделения, двигавшиеся в Персидский поход, а также выполняли тыловые функции для частей Персидского корпуса на протяжении всего времени его существования. В Царицыне, в крепостях на линии и ближайших к линии станицах донских казаков располагалась на зимние квартиры кавалерия Низового корпуса. Здесь драгунские полки проходили переукомплектование, отсюда отдельные части отправлялись в командировки по южным границам России. Царицынская линия внесла серьезные изменения в жизнь кочевого населения Нижнего Поволжья. Переход линии имел важное военное и политическое значение. Группы калмыков, прошедшие «внутрь линии», оказывались отрезанными от кубанцев и крымцев и от других групп калмыков. Для калмыцких владельцев переход линии имел символическое значение, они опасались того, что при переходе Царицынской линии у них будут отобраны 
улусы или они будут насильно обращены в православие. В статье уточнены данные о численности войск, которые несли службу на Царицынской линии в 1720-х гг. Постоянно на линии находились не менее 500 казаков, командировавшихся Донским войском, а также несколько драгунских полков. В 1720-х гг. на Царицынской линии на протяжении различных сроков от нескольких месяцев до нескольких лет несли службу части Кроншлотского, Олонецкого, Вологодского, Тобольского, Московского, Архангелогородского, Дмитровского и Саратовского драгунского полков. Bblвoды. Царицынская линия уже в первые годы после её создания не только защищала южные границы страны, но и стала инструментом дипломатического и военно-политического влияния России на соседние народы и государства.

Ключевые слова: Царицынская линия, Персидский поход, калмыки в 1720-х гг., Петр I, Аюка Благодарность. Работа выполнена в рамках реализации гранта РФФИ «Памятник фортификации Петровской эпохи “Царицынская сторожевая линия”: история строительства и эксплуатации, современное состояние, перспективы музеефикации и туристического использования» (проект № 20-09-42009).

Для цитирования: Клейтман А. Л. Царицынская сторожевая линия и военно-политические изменения на юго-восточных границах России в 1720-х гг. // Oriental Studies. 2021. Т. 14 (5). C. 900-909. DOI: 10.22162/2619-0990-2021-57-5-900-909

\title{
Tsaritsyn Defense Line and Military-Political Changes in Russia's Southeastern Frontier, 1720s
}

\author{
Alexander L. Kleitman ${ }^{1,2}$ \\ Russian Federation) \\ Dr. Sc. (History), Associate Professor \\ Director \\ 0000-0003-4779-0321. E-mail: malk@bk.ru \\ (C) KalmSC RAS, 2021 \\ (C) Kleitman A. L., 2021
}

${ }^{1}$ Volgograd Institute of Management, Branch of RANEPA (8, Gagarin St., 400131 Volgograd,

${ }^{2}$ Volgograd Oblast Research and Production Center for Historical and Cultural Preservation (19, Kommunisticheskaya St., 400131 Volgograd, Russian Federation)

\begin{abstract}
Introduction. The Tsaritsyn defense line has attracted the attention of historians since the $18^{\text {th }}$ century, but so far, no special study of the history of the Tsaritsyn line in the 1720 s has been undertaken. The period is of interest for its policy of strengthening the military-political influence of Russia in the Caspian region, with the Persian campaign undertaken and control over the movements of the Kalmyks increasing. The article aims to show the role of the Tsaritsyn defense line in these events. Materials and methods. The study intends to systematize and reconsider the information about the Tsaritsyn line presented in the historiography of the Persian campaign, in the history of the Kalmyks, and in the history of the regiments of the Russian imperial army, supplementing them with data of legislative acts and office documentation. Results. Tsaritsyn and the Tsaritsyn line were staging points on the path of the formation and movement of the Nizovoi (Lower), or Persian, Corps; practically all military units involved in the Persian campaign passed through the Tsaritsyn line, which was used for rear functions by the Corps as long as it existed. Tsaritsyn, the fortresses on the line, and the villages of the Don Cossacks closest to the line served as winter quarters for the Corps cavalry: here the dragoon regiments were re-equipped, and individual units were sent on missions along the southern borders of Russia. The Tsaritsyn line introduced serious changes in the life of the nomadic population of the Lower Volga region; passages through the line acquiring great military and political importance. Groups of Kalmyks who passed 'inside' turned out to be cut off from the Kuban and Crimeans and from other groups of Kalmyks. There was a symbolic meaning to the crossing of the Tsaritsyn line for Kalmyks who feared that their uluses would be taken away from them or they would be converted to Orthodoxy against their will. The study clarifies the data on
\end{abstract}


the number of troops that served on the Tsaritsyn line in the 1720s. Constant was the presence of at least 500 Cossacks, sent on their mission by the Don army, as well as of several dragoon regiments. In the 1720s, units of the Kronshlots, Olonets, Vologda, Tobolsk, Moscow, Arkhangelsk, Dmitrov, and Saratov dragoon regiments served on the Tsaritsyn line from several months to several years. Conclusions. From the very first years of its construction, the Tsaritsyn line not only protected the southern borders of the Russian Empire, but also became an instrument of the imperial diplomatic and military-political influence on neighboring peoples and states.

Keywords: Tsaritsyn line, Persian campaign, Kalmyks in the 1720s, Peter I, Khan Ayuka

Acknowledgements. The reported study was funded by RFBR, project no. 20-09-42009 'Tsaritsyn Defense Line - A Fortification Monument of Peter the Great's Era: History of Construction and Operation, Current State, Prospects for Museumification and Tourist Use'.

For citation: Kleitman A. L. Tsaritsyn Defense Line and Military-Political Changes in Russia's Southeastern Frontier, 1720s. Oriental Studies. 2021. Vol. 14 (5): 900-909. (In Russ.). DOI: 10.22162/2619-0990-2021-57-5-900-909

\section{Введение}

История Царицынской сторожевой линии привлекала внимание учёных с XVIII в. Отдельные аспекты её истории рассматривались в рамках обобщающих исследований по истории России [Соловьев 1997; Багалей 1887; Павленко 2000; Павленко 2003], истории фортификации [Ласковский 1861], в краеведческих работах [Леопольдов 1839; Минх 1898; Минх 1900а; Минх 1900б; Минх 1901; Минх 1902; Рябов, Самойлов, Супрун 1994; Курышев 2011]. Единственным специальным исследованием, посвященным Царицынской линии, до настоящего времени остаётся работа Т. И. Лавриновой, написанная в конце 1980-х гг. и изданная в виде монографии в 2012 г. [Лавринова 1990; Лавринова 2012]. Отдельного исследования истории Царицынской линии в первое десятилетие её существования до настоящего времени не предпринималось. При этом именно в 1720-х гг. российское правительство стало проводить активную политику на юго-восточных границах империи: начался Персидский поход, произошли серьезные изменения в российско-калмыцких отношениях. В связи с этим существует необходимость проведения специального исследования, в рамках которого будет проанализировано, какую роль сыграла Царицынская линия в данных процессах.

\section{Материалы и методы}

Предпринимавшиеся ранее исследования истории Царицынской линии основывались на законодательных источниках, делопроизводственной документации Сената и Военной коллегии, хранящихся в Российском государственном архиве древних актов (РГАДА) и Российском государственном военно-историческом архиве (РГВИА). Делопроизводственная документация, официальная переписка астраханского губернатора с центральными органами власти, с царицынским воеводой и командирами частей, которые несли службу на Царицынской линии, и ряд других источников, которые были введены в научный оборот исследователями истории калмыцкого народа (классические работы В. М. Бакунина, Н. Н. Пальмова, исследования современных авторов - Д. В. Васильева, Д. В. Сеня, А. В. Цюрюмова и др.), не использовались в качестве источников по истории Царицынской линии. Привлечение данных источников, а также опубликованных историй полков императорской армии, написанных в конце XIX — начале XX вв., и документов Главной канцелярии Артиллерии и фортификации, отложившихся в фондах научного архива Военно-исторического музея артиллерии, инженерных войск и войск связи, позволяет переосмыслить устоявшиеся в историографии взгляды относительно роли Царицынской линии в военно-политических изменениях на юго-восточных границах России в 1720-х гг.

Роль Царицынской сторожевой линии

В августе 1720 г. была закончена работа по строительству Царицынской сторожевой линии, протянувшейся от Царицына на Волге до Качалинского казачьего городка на Дону. Согласно первоначальному замыслу, это оборонительное сооружение должно было обезопасить южные границы России, затруднив проход кубанцев и крымских татар через степи Волго-Донского междуре- 
чья. Западнее территории, где была проложена линия, располагались земли донских казаков, на востоке естественной преградой, создававшей препятствия для свободного перемещения кочевников, была Волга. Укрепление перешейка между Волгой и Доном, размещение на линии регулярной армии и казачьих частей в полной мере решало первоначально поставленную задачу.

Завершение строительства линии совпало по времени с окончанием Северной войны. Правительству необходимо было либо сокращать численность армии, либо ставить новые задачи для освободившихся воинских частей. Петром I было принято решение перебросить войска на южные границы России, направив их на покорение территории на западном и восточном побережье Каспийского моря. Данный регион привлекал внимание Петра с первых лет его правления, в 1710-х гг. предпринимались научные экспедиции для картографирования, составления описания Каспийского моря, предпринимались попытки найти месторождения золота, открыть новые торговые пути, в том числе сухопутный переход в Индию, установить влияние России над данным регионом дипломатическим и отчасти военно-политическим путём [Соймонов 1763; Могутов 1777]. Предпринимавшиеся в 1700-1710-х гг. попытки не позволили решить амбициозные задачи Петра в Прикаспийском регионе.

В 1720 г. началась подготовка к походу российской армии на Каспийское море. В 1721 г. стала проводиться перегруппировка войск с целью формирования нового крупного гарнизона для отправки его в Персидский поход. Пехота Низового корпуса зимой 1721-1722 гг. размещалась в Москве, Ярославле и других городах. Весной 1722 г. на судах по Волге и сухим путём в Астрахань стали стягиваться пехота, драгунские, гвардейские полки [Курукин 2010: 53-54].

Царицын и Царицынская линия стали важными перевалочными пунктами на пути формирования и движения Низового корпуса. Весной 1722 г. к Царицынской линии были стянуты несколько драгунских полков, к ним присоединились части донских и украинских казаков. В мае 1722 г. 10 тысяч казаков под командой атамана И. М. Краснощекова, корпус малороссийских казаков и драгунские полки, находившиеся на линии, под командованием генерала Г. С. Кропотова отправились через степь напрямую к Теркам. С этим же корпусом были отправлены принадлежащие пехотным полкам лошади и артиллерия [Борисов, Сыцянко 1888: 92].

Петр I, лично руководивший войсками, дважды посетил Царицын во время Персидского похода - 15-16 июня 1722 г. по пути на Каспий [Походный журнал 1855: 44-45] и на обратном пути в ноябре этого же года [Походный журнал 1855: 93]. Вместе с царицынским комендантом император осматривал укрепления Царицынской крепости и новой оборонительной линии. Земляные укрепления линии, строившейся в спешке, уже летом 1721 г. частично были разрушены [Иванюк 2021: 43]. Был подготовлен план укрепления линии, который был представлен царицынским комендантом полковником Л. Ю. Селивановым императору на утверждение. Петр утвердил план укрепления линии своей подписью [НА МАИВиВС. Ф. 2. ОП. 2. Д. 261. Л. 363-363об.].

В июне 1723 г. в Военную коллегию поступила копия указа о строении цитадели на Царицыне и подписанный императором план укрепления линии, направленные Л. Ю. Селивановым. По решению Военной коллегии и Главной артиллерии в Царицын был направлен полковник инженер И. Я. Бреклин, находившийся в Астрахани, чтобы провести осмотр и составить детальную смету материалов и работ, необходимых для ремонта укреплений линии [НА МАИВиВС. Ф. 2. Оп. 2. Д. 261. Л. 363-363об., 584-584об., 628-629, 681681об.]. Результатом его обследований стал план Царицынской линии, сохранившийся в фондах отдела рукописей Библиотеки Академии наук [ОР БАН. Ф. Собрание рукописных карт (основная часть). F. 266. Т. 3. Л. 44]. Автор на данном плане указан не был, однако, судя по отображённым постройкам Царицына (за р. Царицей ещё нет застройки), надписи в экспликации «обрубы на бояраках для проходу вешней воды, которые построены в 1720м году», данный план должен быть датирован первой половиной 1720-х гг. Информации о других специальных обследованиях укреплений Царицынской линии в это время, кроме направления на Царицынскую линию полковника инженера И. Я. Бреклина, пока обнаружить не удалось. В пользу того, что именно 
этот специалист был автором указанного плана, может свидетельствовать тот факт, что в фондах Научно-исследовательского отдела рукописей Библиотеки Академии наук (далее - НИОР БАН) сохранился также план цитадели при впадении реки Царицынки в Волгу, составленный в это же время и подписанный И. Я. Бреклиным [ОР БАН. Ф. Собрание рукописных карт (основная часть). Оп. 35. № 833. Л. 1].

Документальных свидетельств того, что в 1720-х гг. проводились работы по укреплению Царицынской линии пока обнаружить не удалось.

Царицынская линия выполняла тыловые функции для частей Персидского корпуса на протяжении всего времени его существования. В Царицыне, в крепостях на линии и ближайших к линии станицах донских казаков располагалась на зимние квартиры кавалерия Низового корпуса как для того, чтобы обезопасить её от неприятеля, так и для того, чтобы доукомплектовать части лошадьми [Бутков 1869: 36]. Здесь драгунские полки проходили переукомплектование, отсюда отдельные части отправлялись в командировки по южным границам России. 31 июля 1729 г. был издан высочайший указ о том, чтобы все штаб- и обер-офицеры Персидского корпуса менялись каждые три года офицерами, несшими службу на Царицынской линии [Борисов, Сыцянко 1888: 98-99].

Царицынская линия внесла серьезные изменения в жизнь кочевого населения Нижнего Поволжья. Калмыки, бывшие наиболее многочисленными кочевниками Заволжья и правобережья Волги в районе от Астрахани до Саратова, были разделены на несколько кланов, находившихся как между собой, так и русским оседлым населением региона в отношениях, сочетавших мирное взаимодействие, торговлю с вооруженными столкновениями и грабежами. В 1710-х гг. отдельные группы калмыков принимали участие в разорительных нападениях кубанского султана Бахты-Гирея на русские земли. При этом русское правительство и сам Пётр I активно взаимодействовали с калмыцким ханом Аюкой, воинские подразделения калмыков принимали участие в боевых действиях Северной войны, поддерживали русскую армию во время Персидского похода.
Взаимоотношения кочевников данного региона осложнились после смерти в 1724 г. калмыцкого хана Аюки - важнейшего союзника России, объединявшего под своей властью большую часть калмыков, и начавшейся междоусобной борьбой за власть среди его наследников. Часть калмыцких тайшей стали поддерживать султана Бахты-Гирея, регулярно совершавшего разорительные походы на южные окраины России. Значительная часть калмыцких владельцев поддерживали вдову хана Аюки Дарма-Балу.

Царицынская линия стала серьезным рубежом на пути движения калмыков. Для того чтобы пройти «внутрь линии», необходимо было разрешение астраханского губернатора. При этом переход линии имел важное военное и политическое значение. Группы калмыков, прошедшие «внутрь линии», оказывались отрезанными от кубанцев и крымцев и от других групп калмыков. Давая разрешение или запрещая переход через линию, астраханский губернатор контролировал их взаимоотношения, пытаясь избежать нападений калмыков на русские земли или обострения отношений с крымским ханом и Османской империей.

Несколько инцидентов, ярко иллюстрирующих, как изменилась жизнь кочевого населения Нижнего Поволжья после создания Царицынской линии, нашли отражение в сочинении В. М. Бакунина, жителя Царицына, выучившего калмыцкий язык и в 1720-х гг. служившего переводчиком при калмыках, а также в делопроизводственной документации, официальной переписке этого времени.

Весной 1724 г. вдова хана Аюки Дарма-Бала обратилась к правительству Петра I с просьбой пропустить калмыцкие улусы через Царицынскую линию под защиту русских войск для защиты от возможных нападений кубанцев. Сенат принял решение удовлетворить просьбу ханши, разрешив пройти через линию улуса как улусам Дарма-Балы, так и всем калмыцким владельцам, которые этого захотят. В мае 1724 г. командующий войсками, расположенными на Царицынской линии, Я. С. Шамордин донёс в Военную коллегию, что калмыки благополучно перешли через линию [Лавринова 2012: 64]. В июне 1724 г. улусы Дондук-Омбо и ханши Дарма-Балы кочевали «внутри 
линии», между Бузулуком и Медведицей в верховьях речки Кумылги. Летом часть калмыцких владельцев решила уйти на Кубань, переправившись через Дон или перейдя через Царицынскую линию.

Детальный анализ делопроизводственной документации, переписки Я. С. Шамордина, А. П. Волынского между собой, а также с Сенатом и Военной коллегией, предпринятый Н. Н. Пальмовым, убедительно показывает, что российские войска, расположенные на Царицынской линии, летом 1724 г. не столько охраняли калмыков от нападений кубанцев, сколько контролировали их передвижения, добиваясь того, чтобы калмыцкие владельцы выбрали наследника хана Аюки и принесли присягу российскому императору. 19 сентября второй сын хана Аюки Церен-Дондук принял присягу императору, а другие калмыцкие владельцы обязались повиноваться ему как ханскому наместнику до тех пор, пока не будет назначен новый хан [Васильев 2015: 351-357]. Дондук-Омбо не принял этого решения и вступил в борьбу за ханский титул, продолжавшуюся несколько последующих лет. В ноябре калмыки были пропущены через линию, при этом, по сведениям В. М. Бакунина, Дондук-Омбо, опасаясь быть схваченным русскими властями из-за конфликтов с донскими казаками, имевшими место летом 1724 г., переезжал линию в коробе, навьюченном на верблюда [Бакунин 1995: 44].

Переход через линию приобрел символическое значение. В начале 1725 г. один из калмыцких владельцев Нитар-Доржи делился с В. М. Бакуниным опасениями относительно перехода внутрь линии: он боялся, что его повесят за то, что обещал ранее креститься, но солгал, а также что его улусы будут крещены насильно или будут отобраны те улусы, которые он ранее отобрал у братьев. В. М. Бакунин возражал, что призыв в линию чинился исключительно для того, чтобы защищать калмыков от неприятелей и примирить калмыцких владельцев между собой. Опасения Нитар-Доржи были не напрасны. Поддавшись на уговоры В. М. Бакунина, он со своими улусами перешёл Царицынскую линию и расположился в степях между Царицыном и Дмитровском. Здесь разгорелся конфликт Нитар-Доржи с приехавшим из Петербурга его родным братом Петром Тайшиным, за год до этого принявшим крещение и полагавшим, что на этом основании он может претендовать на ханский престол [Джунджузов 2020: 534-535]. Самому Петру Тайшину удалось скрыться, но один из его спутников был убит, и несколько человек фактически оказались в заложниках. Нитар-Доржи пытался также напасть на А. П. Волынского, двигавшегося сухим путём из Царицына в Саратов, избил и грозился убить В. М. Бакунина, отправленного к нему губернатором для переговоров. В результате против Нитар-Доржи было направлено войско, стоявшее на Царицынской линии, было убито около ста и поймано около 60 калмыков. Самому Нитар-Доржи удалось скрыться, однако вскоре он был убит братом Досангом, побоявшимся, что гнев российских властей на Нитар-Доржи будет обращен также и на него [Бакунин 1995: 52-53; Тепкеев 2021б: 239-245].

В связи с проведением Царицынской линии существенно возросло значение Царицынской крепости и расширились функции их воевод. Помимо сугубо военных они стали выполнять дипломатические функции по взаимодействию с калмыцкими и кубанскими военно-политическими лидерами. Царицынским воеводам поступала информация о перемещениях, вооруженных столкновениях отдельных групп калмыков между собой и с внешними врагами. В Царицыне и на линии происходили встречи с владельцами калмыцких улусов и их посланниками [Тепкеев 2021: 26-27]. Царицынские воеводы встречались и вели переговоры с посланниками Бахты-Гирея. Им поручалось взаимодействовать с зайсангами, чтобы не допустить присоединения калмыков к войску Бахты-Гирея и последующего осложнения отношений с крымским ханом и Османской империей [Сень 2019: 148].

\section{Численность войск, несших службу на Царицынской линии}

До настоящего времени не предпринималось специальных попыток проанализировать численность войск, которые несли службу на Царицынской линии в 1720-х гг. Хотя уже введенные в научный оборот Н. Н. Пальмовым, Т. И. Лавриновой, И. Н. Курукиным, авторами полковых историй конца XIX - начала XX вв. источники позволяют достаточно подробно осветить данный вопрос. 
Каждый год для службы на Царицынской линии Донское войско направляло не менее 500 казаков [Курышев 2011: 17].

В июне 1722 г. в Сенате было принято решение расположить на Царицынской линии Кроншлотский и Олонецкий драгунские полки, поскольку от донских казаков поступила информация, что крымский хан собирал на Кубани войска, чтобы выступить против Низового корпуса. В августе к Царицынской линии подошел Кроншлотский драгунский полк под командованием П. И. Бутурлина и по Волге прибыл отряд Олонецкого полка, возглавляемый капитаном Вильяшовым. По данным Т. И. Лавриновой, до прибытия этих частей на Царицынской линии располагался отряд донских казаков (483 человека) и отряд гарнизонных солдат поволжских городов (198 человек). После прибытия драгунских полков общая численность нового воинского соединения составила 2297 человек [Лавринова 2012: 58-59].

В сентябре 1722 г. Военная коллегия приняла решение об отводе драгунских полков на зимние квартиры в Симбирскую и Пензенскую провинции. При Царицынской линии на зиму 1722/1723 гг. были оставлены части драгунских Московского, Архангелогородского, Дмитровского и Саратовского батальонов и донских казаков [Лавринова 2012: 60].

В 1724 г. под командованием бригадира Я. С. Шамордина на Царицынской линии находились Кроншлотский, Вологодский, Олонецкий и Тобольский кавалерийские полки. Общая их численность составляла более 3300 человек, однако многие из них находились в командировках. В письме А. П. Волынскому Я. С. Шамордин отмечал, что численность боеспособных людей в его команде составляла 903 человека [Пальмов 1929: 205-207].

Через Царицынскую линию шло постоянное движение частей, направлявшихся в Низовой корпус или отводившихся на зимние квартиры. В условиях постоянного движения войск и часто возникавших конфликтов с калмыками не всегда линия была в полной мере надёжно защищена.

Так, в июле 1724 г. бригадир Я. С. Шамордин жаловался, что на линии было «весьма малолюдно». Большая часть личного состава была больна. Опасаясь, что он не сможет сдержать калмыков, если они решат пересечь линию, Я. С. Шамордин обратился за помощью к полковнику гадячского полка Милорадовичу, который вёл с Украины к Сулаку 7 тыс. казаков, чтобы тот задержался в Царицыне. В начале августа к линии подошли части Новотроицкого и Луцкого полков численностью 800 человек, и полк Милорадовича смог дальше двинуться в Астрахань [Пальмов 1929: 205-207].

Летом 1725 г. на Царицынской линии было размещено несколько драгунских полков под командованием бригадира Ветерани [Бакунин 1995: 52]. В полковой истории Вятского драгунского полка, входившего в состав Низового корпуса, упоминалось, что в 1725 г. на зимних квартирах в донских казачьих городках Иловле, Качалине и других располагались 606 человек, практически столько же было в командировках по крымской и польской границам и задействовалось для содержания почты [История 1901: 78]. На следующий год большая часть этого полка была отправлена на «вечные» квартиры в Свияжск, но 2 офицера и 171 драгун были командированы на Царицынскую линию и в крепость Св. Креста [История 1901: 82].

В 1728 г. при линии был образован Царицынский корпус из 6 полков, командиром которого стал генерал-лейтенант Чекин [Камолов 2009: 11]. В ноябре 1728 г. в станицах на Дону были размещены 2 драгунских полка и приготовлены 2000 казаков, чтобы весной разорить улус Дондук-Омбо. Весной 1729 г. эти полки были также размещены на Царицынской линии [Бакунин 1995: 64].

\section{Заключение}

Уже в первые годы после создания Царицынской линии её военно-политические функции вышли далеко за пределы оборонительного сооружения, предотвращавшего набеги кубанцев и крымских татар на русские земли. Царицынская линия, сформировав линейную границу Российского государства в стратегически важном месте Волго-Донского междуречья, стала важным фактором сложных и противоречивых хозяйственных, военных и дипломатических отношений кочевых народов, населявших степи Приазовья, Северного Причерноморья, Северного Прикаспия, Кубани. Царицынская линия разделила ранее единую территорию кочевий калмыков, позволила кон- 
тролировать перемещение калмыцких улусов по их традиционным маршрутам, став важным инструментом влияния российского правительства на социальные, политические, военные процессы, происходившие в калмыцком обществе. Царицынская линия сыграла важную роль в организации Персидского похода. Будучи крупнейшим оборонительным сооружением, располагавшимся невдалеке от театра боевых действий, Царицынская линия стала ближним тылом Низового корпуса, куда отводились части, выходившие из боевых действий, на зимние квартиры, на доукомплектование людьми и лошадьми. Царицынская линия была крупнейшим линейным оборонительным сооружением, созданным в России во время

\section{Источники}

НА МАИВиВС - Научный архив Музея артиллерии, инженерных войск и войск связи. Ф. 2. ОП. 2. Д. 261.

ОР БАН - Отдел рукописей Библиотеки Академии наук. Ф. Собрание рукописных карт (основная часть).

Походный журнал 1855 - Походный журнал 1722 г. СПб.: б. и., 1855. 194 с.

\section{Литература}

Багалей 1887 - Багалей Д. И. Очерки из истории колонизации и быта степной окраины Московского государства. М.: Имп. общ-во истории и древностей рос. при Моск. ун-те, $1887.614 \mathrm{c}$.

Бакунин 1995 - Бакунин В. М. Описание калмыцких народов, а особливо из них торгоутского, и поступков их ханов и владельцев: Соч. 1761 г. Элиста: Калм. кн. изд-во, 1995. $153 \mathrm{c}$.

Борисов, Сыцянко 1888 - Борисов В., Сыцянко $A$. Походы 64-го пехотного Казанского Его Императорского Высочества Великого князя Михаила Николаевича полка. 1642 1700-1886. СПб.: Тип. И. Н. Скороходова, $1888.519 \mathrm{c}$.

Бутков 1869 - Бутков П. Г. Материалы для новой истории Кавказа, с 1722 по 1803 год. Т. 1. СПб.: Тип. Имп. Акад. наук, 1869. 548 с.

Васильев 2015 - Васильев Д. В. Становление калмыцкого ханства как субъекта российской империи. XVII - первая половина XVIII в. // Известия Самарского научного центра РАН. 2015. № 3-2. С. 351-357.

Джунджузов 2020 - Джунджузов С. В. Перипетии судьбы калмыцкого владельца Пе- правления Петра I. Первые годы существования линии показали правительству, что подобные сооружения позволяют не только зафиксировать границы государства, но могут быть использованы как жесткий и эффективный инструмент в выстраивании дипломатических отношений с кочевым населением региона. В начале 1730 -х гг. началось строительство новых, гораздо более протяженных линейных укреплений на южных границах страны - Украинской, Новой Закамской и Оренбургской линии. При их строительстве и при организации службы на них активно использовался опыт, приобретенный правительством и армейскими частями на Царицынской линии.

\section{Sources}

Library of the Russian Academy of Sciences, Manuscript Department. Coll. of Handwritten Maps (main part).

Museum of Artillery, Engineering Troops and Signal Corps; Scientific Archive. Coll. 2. Cat. 2. File 261. (In Russ.)

The 1722 Campaign Diary. St. Petersburg, 1855. 194 p. (In Russ.)

тра Тайшина: от принятия христианства до создания поселения крещеных калмыков в Среднем Поволжье (1724-1737 гг.) // Вестник Российского университета дружбы народов. Серия: История России. 2020. Т. 19. № 3. C. 525-543. DOI: $10.22363 / 2312-8674-$ 2020-19-3-525-543

Иванюк 2021 - Иванюк С. А. Фортификационные особенности оборонительных сооружений Царицынской сторожевой линии в 20-х гг. XVIII века // Вестник Волгоградского государственного университета. Серия 4: История. Регионоведение. Международные отношения. 2021. № 1. С. 41-52. DOI: 10.15688/jvolsu4.2021.1.5

История 1901 - История 35-го Драгунского Белгородского Его Величества Императора Австрийского Короля Венгерского Франца-Иосифа I полка / сост. Штабс-Ротмистр П. Е. Червинский. Киев: Тип. С. В. Кульженко, 1901. 198 с.

Камолов 2009 - Камолов Н. А. Царицынская линия во второй - третьей четверти XVIII века // Вестник Воронежского государственного университета. Серия: История. Политология. Социология. 2009. № 1. C. 11-19. 
Курукин 2010 - Курукин И. В. Персидский поход Петра Великого. Низовой корпус на берегах Каспия (1722-1735). М.: Квадрига, 2010. $381 \mathrm{c}$.

Курышев 2011 - Курышев А. В. Волжское казачье войско (1730-1804): создание, развитие и преобразование в линейные казачьи полки. Волгоград: Издатель, 2011. 352 с.

Лавринова 1990 - Лавринова Т. И. Царицынская линия: история строительства в 1718 1720 гг. и первые годы существования: дисс. ... канд. ист. наук. Воронеж, 1990. 199 с.

Лавринова 2012 - Лавринова Т. И. Царицынская линия: история строительства в 17181720 гг. и первые годы существования. Волгоград: Издатель, 2012. 93 с.

Ласковский 1861 - Ласковский Ф. Ф. Материалы для истории инженерного искусства в России: в 3-х ч. Ч. 2. Опыт исследования инженерного искусства в царствование императора Петра Великого. СПб.: Тип. Имп. Акад. наук, 1861. 642 с.

Леопольдов 1839 - Леопольдов А. Ф. Статистическое описание Саратовской губернии. в 2 ч. Ч. 2. СПб.: Тип. Деп. внеш. торг., 1839. $143 \mathrm{c}$.

Минх 1898 - Минх А. Н. Историко-географический словарь Саратовской губернии. Т. 1. Вып. 1. Саратов: Тип. губернского земства, 1898. C. 1-208.

Минх 1900а - Минх А. Н. Историко-географический словарь Саратовской губернии. Т. 1. Вып. 2. Саратов: Тип. губернского земства, 1900. C. 209-278.

Минх $1900 б-$ - инх А. Н. Историко-географический словарь Саратовской губернии. Т. 1. Вып. 2. Продолжение. Саратов: Тип. губернского земства, 1900. С. 279-556.

Минх 1901 - Минх А. Н. Историко-географический словарь Саратовской губернии. Т. 1. Вып. 3. Саратов: Тип. губернского земства, 1901. C. 557-1092.

Минх 1902 - Минх А. Н. Историко-географический словарь Саратовской губернии. Т. 1. Вып. 4. Актарск: Аткарская тип., 1902. C. $1093-1410$.

Могутов 1777 - Могутов В. Редкое и достопамятное известие, о бывшей из России в

\section{References}

Bagaley D. I. Colonization and Everyday Life: Historical Essays on Muscovy and Steppe Peripheries. Moscow: Imperial Society of Russian History and Antiquities (Moscow University), 1887. 614 p. (In Russ.)
Великую Татарию экспедиции, под имянем Посольства: Принадлежащее к пользе, в службе находящимся и в коммерции упражняющимся. СПб.: Тип. Вейтбрехта и Шнора, $1777.63 \mathrm{c}$.

Павленко 2000 - Павленко Н. И. Петр І. М.: Молодая гвардия, 2000. 428 с.

Павленко 2003 - Павленко Н. И. Екатерина Великая. М.: Молодая гвардия, 2003. 495 с.

Пальмов 1929 - Пальмов Н. Н. Этюды по истории волжских калмыков. Ч. III и ч. IV. Ограничительные мероприятия правительства в отношении к калмыкам. Первый том исследования. XVII век и начало XVIII века. Астрахань: Тип. Калмиздата, 1929. 392 с.

Рябов, Самойлов, Супрун 1994 - Рябов С. И., Самойлов Г. П., Супрун В. И. Петр Великий в Царицыне и на Среднем Дону. Волгоград: Издательство ВГПУ «Перемена», 1994. 174 с.

Сень 2019 - Сень Д. В. Взаимоотношения калмыков и кубанского султана Бахты-Гирея: тактика и стратегия пограничного сотрудничества (середина — вторая половина 1720-х гг.) // Magna adsurgit: historia studiorum. 2019. № 1. C. 125-161. DOI: 10.22162/2541-9749-2019-7-1-125-161

Соймонов 1763 - Соймонов Ф. И. Описание Каспийского моря и чиненных на оном российских завоеваний, яко часть истории государя императора Петра Великого, трудами тайного советника, губернатора Сибирии ордена святого Александра кавалера Федора Ивановича Соймонова. СПб.: Императорская акад. наук, 1763. 380 с.

Соловьев 1997 - Соловьев С. М. Сочинения: в 18 книгах. Кн. 9. История России с древнейших времен. Т. 17-18. М.: Голос, 1997.708 с.

Тепкеев 2021a - Тепкеев В. T. Калмыцко-казахское противостояние в Северном Прикаспии в 1723-1724 гг. // Oriental Studies. 2021. № 1. C. 24-32. DOI: 10.22162/2619-0990-2021-531-24-32

Тепкеев 2021б - Тепкеев В. T. В поисках выхода из политического кризиса в Калмыцком ханстве: организация убийства Нитар-Дорджи в 1725 г. // Монголоведение. 2021. Т. 13. № 2. C. 231-247. DOI: $10.22162 / 2500-1523-2021-$ 2-231-247

Bakunin V. M. Description of the Kalmyk Peoples, in Particular Torgout People, and Deeds of Their Khans and Landlords (1761). Elista: Kalmykia Book Publ., 1995. 153 p. (In Russ.)

Borisov V., Sytsyanko A. 64 ${ }^{\text {th }}$ Infantry Kazan Regiment of His Imperial Highness Grand 
Duke Mikhail Nikolaevich: Campaigns, 1642 1700-1886. St. Petersburg: I. N. Skorokhodov, 1888. 519 p. (In Russ.)

Butkov P. G. Recent History of the Caucasus, 1722 to 1803: Collected Materials. St. Petersburg: Imperial Academy of Sciences, 1869. Vol. 1. 548 p. (In Russ.)

Chervinsky P. E. (comp.) $35^{\text {th }}$ Dragoon Belgorod Regiment of His Majesty Franz Joseph I, Emperor of Austria and King of Hungary: A History. Kiev: S.V. Kulzhenko, 1901. 198 p. (In Russ.)

Dzhundzhuzov S. V. The vicissitudes of the fate of the Kalmyk nobleman Petr Taishin: From the adoption of Christianity to the establishment of a settlement of baptized Kalmyks in the Middle Volga Region (1724-1737). RUDN Journal of Russian History. 2020. Vol. 19. No. 3. Pp. 525543. (In Russ.)

Ivanyuk S. A. Features of fortifications of the Tsaritsyn Defense Line in the 20 s of the $18^{\text {th }}$ century. Science Journal of Volgograd State University. History. Area Studies. International Relations. 2021. No. 1. Pp. 41-52. (In Russ.)

Kamolov N. A. Tsaritsyn Defense Line, 1720s-1770s. Proceedings of Voronezh State University. Series: History. Political Science. Sociology. 2009. No. 1. Pp. 11-19. (In Russ.)

Kurukin I. V. Persian Campaign of Peter the Great: A Local Corps in the Caspian Shore, 17221735. Moscow: Kvadriga, 2010. 381 p. (In Russ.)

Kuryshev A. V. Volga Cossack Host, 1730-1804: Creation, Development, and Transformation into Cossack Defense Line Regiments. Volgograd: Izdatel, 2011. 352 p. (In Russ.)

Laskovsky F. F. Engineering Arts in Russia: Historical Materials. In 3 vols. Vol. 2: Peter the Great's Era. St. Petersburg: Imperial Academy of Sciences, 1861. 642 p. (In Russ.)

Lavrinova T. I. Tsaritsyn Defense Line: History of Construction (1718-1720) and Earliest Years of Existence. Cand. Sc. (history) thesis. Voronezh, 1990. 22 p. (In Russ.)

Lavrinova T. I. Tsaritsyn Defense Line: History of Construction (1718-1720) and Earliest Years of Existence. Volgograd: Izdatel, 2012. 93 p. (In Russ.)

Leopoldov A. F. Saratov Governorate: A Statistical Description. In 2 vols. St. Petersburg: Foreign Trade Dept., 1839. 143 p. (In Russ.)

Minkh A. N. Saratov Governorate: A Historical and Geographical Dictionary. Vol. 1. Parts 1-3.
Saratov, 1898, 1900, 1901. Vol. 1. Part 4. Aktarsk, 1902. (In Russ.)

Mogutov V. From Russia to Tartary: A Rare and Notable Account of One Embassy-Ranked Expedition Useful to Government Officers and Commercial Agents. St. Petersburg: Weitbrecht \& Schnor, 1777. 63 p. (In Russ.)

Palmov N. N. The Volga Kalmyks: Historical Essays. Parts III-IV: Restrictive Measures of Government towards Kalmyks. Vol. 1: $17^{\text {th }}$ and Early $18^{\text {th }}$ Centuries. Astrakhan: Kalmizdat, 1929. 392 p. (In Russ.)

Pavlenko N. I. Catherine the Great. Moscow: Molodaya Gvardiya, 2003. 495 p. (In Russ.)

Pavlenko N. I. Peter the Great. Moscow: Molodaya Gvardiya, 2000. 428 p. (In Russ.)

Ryabov S. I., Samoylov G. P., Suprun V. I. Peter the Great in Tsaritsyn and the Middle Don. Volgograd: Peremena, 1994. 174 p. (In Russ.)

Sen D. V. Relations between Kalmyks and Kuban Sultan Bahti Geray: tactics and strategy of frontier cooperation, mid to late $1720 \mathrm{~s} . M A G N A$ ADSURGIT: HISTORIA STUDIORUM. 2019. No. 1. Pp. 125-161. (In Russ.)

Soimonov F. I. Description of the Caspian Sea and Related Russian Conquests as Part of Peter the Great's History Authored by Fedor Ivanovich Soimonov, Privy Councillor, Governor of Siberia, and Recipient of the Order of St. Alexander Nevsky. St. Petersburg: Imperial Academy of Sciences, 1763. 380 p. (In Russ.)

Solovyov S. M. Complete Works. In 18 books. Book 9: History of Russia from Earliest Times. Vols. 17-18. Moscow: Golos, 1997. 708 p. (In Russ.)

Tepkeev V. T. The Northern Caspian, 1723-1724: Kalmyk-Kazakh confrontation. Oriental Studies. 2021. Vol. 14. No. 1. Pp. 24-32. (In Russ.) DOI: 10.22162/2619-0990-2021-53-124-32

Tepkeev V. T. Surmounting Political Crisis in Kalmyk Khanate: Background and Arrangement of Nitar-Dorji's Assassination in 1725. Mongolian Studies. 2021. No. 2. Pp. 231-247. (In Russ.) DOI: 10.22162/25001523-2021-2-231-247

Vasilyev D. V. Formation of the Kalmyk Khanate as a subject of the Russian Empire since the $17^{\text {th }}$ century to the middle of the $18^{\text {th }}$ century. Izvestiya Samarskogo nauchnogo tsentra Rossiyskoy akademii nauk. 2015. No. 3-2. Pp. 351-357. (In Russ.) 